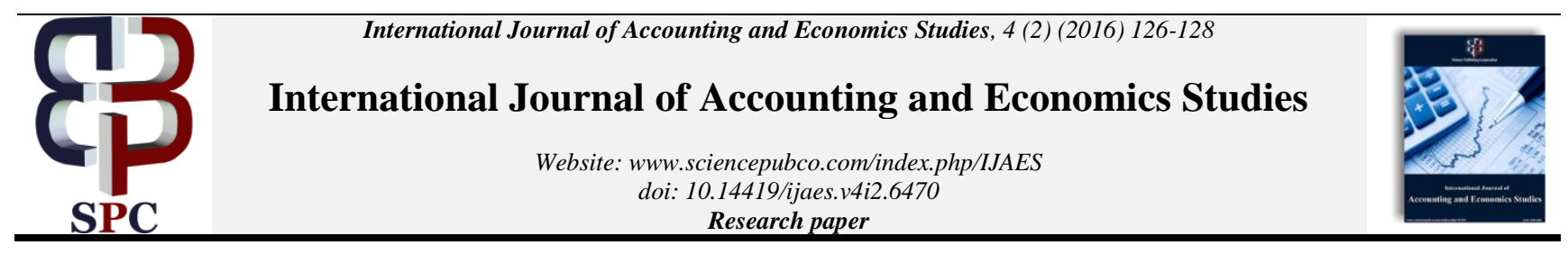

\title{
The relationship between managerial overconfidence with basic metals firms value
}

\author{
Mahmoud Lari Dashtbayaz $^{1 *}$, Shaban Mohammadi ${ }^{2}$ \\ ${ }^{1}$ Assistant Professor in Accounting, Qaenat Branch, Islamic Azad University, Qaen, Iran \\ ${ }^{2}$ M.A student Hakim Nezami University of Quchan, Quchan, Iran \\ *Corresponding author E-mail: shaban1362@gmail.com
}

\begin{abstract}
The purpose of the present study is to investigate the relationship between Managerial overconfidence and Basic metals firm value of the listed companies on the Tehran Stock Exchange (TSE).The population includes 25 firms selected through systematic sampling. The data is collected from the audited financial statements of the firms provided by TSE's website from 2010 to 2015 . In this study the variables, Overconfidence based on earning per share (OEPS), Overconfidence based on capital cost (OCC) has been used to investigate Managerial overconfidence. The results of multiple linear regression analysis show that there is a significant relationship between Overconfidence based on earning per share (OEPS) and firm value. In addition, there is a significant relationship between Overconfidence based on capital cost (OCC) and firm value. The present research examined the relationship between Managerial overconfidence and Basic metals firm's value of the Basic metals firms listed in Tehran Stock Exchange. The results of multivariate regression accepted two the hypotheses of the research. There is a significant relationship between Managerial overconfidence and Basic metals firm value.
\end{abstract}

Keywords: Managerial Overconfidence; Firm Value; Financial Leverage; Firm Size.

\section{Introduction}

The behavioral phenomenon of overconfidence is well established in the psychology literature.4 Examples of overconfidence have been found in studies that address diverse professions and activities. The evidence of the phenomenon has become so evident that researchers have been prompted to term it "the most robust finding in the psychology of judgment". Overconfidence is seen in the Winner's Curse and in the examination of attribution bias where favorable outcomes are more likely attributed to the actors. When individuals choose options, it may be that there is a tendency to choose the option that is more likely over-estimated (Van der Steen, 2004). In many instances, managers make decisions that cannot be explained by expected values and variance of projected outcomes. This discussion suggests that overconfidence is not a trait that is recognized by the affected individual. In the management literature, overconfidence includes both optimism (a positive overestimation in projected outcomes) and overconfidence (an increased confidence in the likelihood of outcomes. Overconfidence has been described as an over-estimation of the precision of private information (Gervais, et al., 2003). Optimism suggests a consistent positive bias in estimation. Both overconfidence and optimism are examples of positive bias in the projections of outcomes. Applied research is research that uses basic research findings to improve and integrity in the behavior, methods, tools, equipment, products, structures and patterns of human societies is used. The purpose of this study is the discovery of new knowledge about the process in the fact that the application of appropriate follow. The objectives of this study are as follows:

1) Helping to provide correct economic decisions.
2) Prevent mistake submitting the report. and tends to adequate supervision on the managers.

3) The director of the company and those who are involved in whose appointment or dismissal, the results of the study can inform the user of the existence of overconfidence in the CEO and its effect on his decisions, every day.

4) IS there a significant relationship between managerial overconfidence and firm value?

5) If there is a significant relationship between managerial overconfidence and firm value, is it a positive relationship or negative relationship?

\section{Review of literature}

Ahmed and Duellman (2012) predicted that overconfident managers will tend to delay loss recognition and generally use less conservative accounting. They tested whether external monitoring helps to mitigate this effect. Using measures of both conditional and unconditional conservatism respectively, they found robust evidence of a negative relation between CEO overconfidence and accounting conservatism. They further found that external monitoring does not appear to mitigate this effect. Their findings added to the growing literature on overconfidence and complement the findings in Schrand and Zechman (2011) that overconfidence affects financial reporting behavior. Huanga, et al (2011) examined the effect of agency cost on the relation between top executives' overconfidence and investment-cash flow sensitivity using the data from Chinese listed companies. They found that on average top executives' overconfidence leads to increased investmentcash flow sensitivity. However, this relation holds only for com- 
panies with state-owned entities as controlling shareholders. In contrast, the relation is not significant for non-state controlled firms. They constructed proxy for agency cost and found that state-controlled companies have significantly greater agency cost than non-state controlled companies. Results on sub-samples sorted by agency cost again showed that the positive effect of top executives' overconfidence on investment-cash flow sensitivity holds only for companies that exhibit high agency cost. Their results therefore suggested that agency cost has a significant impact on the relation between top executives' overconfidence and investment-cash flow sensitivity, and the investment distortion due to top executives' overconfidence behavior may be alleviated by reducing agency cost through elevated supervision. Liu and Taffler (2007) used a large sample of about 1,900 M\&A deals from 1993 to 2005, and data on more than 3,100 CEOs, They explored merger and acquisition activities from a behavioral perspective, and provide another explanation of M\&A motives and firm stock performance. They empirically tested if overconfident CEOs are more likely to conduct mergers than rational CEOs They also examined the impact of CEO overconfidence bias on market reaction to firm M\&A announcements, and also long-term post-M\&A stock returns Three proxies for CEO overconfidence are used in this study: the option-based Holder 67 measure, CEO media portrayal, and content analysis of CEO speech. They found evidence that overconfident CEOs are more likely to conduct mergers and acquisitions than economically rational CEOs. Acquiring firm $\mathrm{CEO}$ overconfidence also has a significantly negative impact on both short-term and long-term post-M\&A. In addition, their results showed that target firm CEO overconfidence similarly negatively affects acquiring firm short-term performance. However, They found that effective corporate governance mechanisms ameliorate, to some extent, the adverse impact of overconfidence bias on M\&A activities. Malmendier and Tate (2005) argued that managerial overconfidence can account for corporate investment distortions. Overconfident managers overestimate the returns to their investment projects and view external funds as unduly costly Thus, they overinvested when they had abundant internal funds, but curtail investment when they require external financing. They tested the overconfidence hypothesis, using panel data on personal portfolio and corporate investment decisions of Forbes 500 CEOs They classified CEOs as overconfident if they persistently fail to reduce their personal exposure to company specific risk. They found that investment of overconfident CEOs is significantly more responsive to cash flow, particularly in equity-dependent firms. (Presley, Abbott, 2013) examined the impact CEO characteristic CEO overconfidence on the incidence of financial restatement. They utilized a matched-pairs research design consisting of 75 restatement firms (obtained through the GAO restatement sample) and a set of 75 non-restatement control firms. Using an optionsbased measure of CEO overconfidence developed by (Malmendier, Tate, 2008), they documented a statistically significant positive relation between CEO overconfidence and financial statement restatement. skala (2008) reviewed the literature on one of the most meaningful concepts in modern behavioural finance, the overconfidence phenomenon. Overconfidence is presented as a well-developed psychological theory, with main facets comprising miscalibration, better-than-average effect, illusion of control and unrealistic optimism. The primary applications of overconfidence in contemporary finance are analyzed, from the perspective of financial markets and corporate behavioral. Experimental studies, formal models and analyses of market data demonstrated that overconfidence at least partially solves some financial market puzzles that cannot be accounted for by standard economic theory. Overconfidence in the corporate context may affect not only a company's internal financing structure, but also its interactions with other market participants through merger and acquisition activity.

\section{Hypotheses and methodology}

First hypothesis: there is a significant relationship between Overconfidence based on earning per share (OEPS) and firm value.

Second hypothesis: there is a significant relationship between Overconfidence based on capital cost (OCC) and firm value. The present research studies one type of industries; the Basic metals listed companies on the TSE. The sample comprises firms that meet the following conditions:

1) Firms that have been listed in the stock exchange before 2015;

2) Firms whose financial year-ends at the end of the Iranian calendar;

3) Firms that have no financial year changes;

4) Firms that have been operating in TSE during the period of interest;

5) Firms that have data available for the period of interest;

6) Investment companies are excluded.

Given these conditions, 30 firms were selected as sample.

Variables Independent

Overconfidence based on earning per share (OEPS):

The present research uses the model proposed by (Huang et al., 2011) and (Pirmoradi et al., 2013) for OEPS.

Overconfidence based on capital cost (OCC):

The present research uses the model proposed by (Malmendier, Tate, 2005) and (Pirmoradi et al., 2013) for OCC.

Capital cost $=\frac{\left(\mathrm{FAP}_{\mathrm{t}}-\mathrm{FAPS}_{\mathrm{t}}\right)-\left(\mathrm{FAP}_{\mathrm{t}-1}-\mathrm{FAPS}_{\mathrm{t}-1}\right)}{\mathrm{NFA}_{\mathrm{t}-1}}$

Dependent variable

In this study, the dependent variable is firm value (VAL). The present research uses the model proposed by (King, Santor, 2008) for VAL.

Control variable

In this study, the control variables are firm size (SIZE) and financial leverage (LEV).

Research model

VAL $_{i, \mathrm{t}}=\beta_{0}+\beta_{1} \operatorname{COC1}_{\mathrm{i}, \mathrm{t}}+\beta_{2}$ LEVERAGE $_{\mathrm{i}, \mathrm{t}}+\beta_{3}$ SIZE $_{\mathrm{i}, \mathrm{t}}+$
$\beta_{4}$ Industry $_{\mathrm{i}, \mathrm{t}}+\varepsilon_{\mathrm{i}, \mathrm{t}}$

$\operatorname{VAL}_{i, \mathrm{t}}=\beta_{0}+\beta_{1}$ COC1 $_{\mathrm{i}, \mathrm{t}}+\beta_{2}$ LEVERAGE $_{\mathrm{i}, \mathrm{t}}+\beta_{3}$ SIZE $_{\mathrm{i}, \mathrm{t}}+$ $\beta_{4}$ Industry $_{\mathrm{i}, \mathrm{t}}+\varepsilon_{\mathrm{i}, \mathrm{t}}$

Size $_{i, t}:$ Natural logarithm of total assets for firm $\mathrm{i}$ in year $\mathrm{t}$.

$\mathrm{LEV}_{\mathrm{i}, \mathrm{t}}$ : Financial Leverage for firm $\mathrm{i}$ in year $\mathrm{t}$.

Multivariate regression analysis was applied at the 5\% significance level for testing the hypotheses.

\section{Findings and descriptive statistics}

Descriptive and inferential (multivariate regression analyses) analyses are used for testing the hypotheses of the research. The data is collected from 30 samples firms listed in Tehran Stock Exchange for the period from 2010 to 2015. Table 1 provides mean, median, standard deviation, maximum, and minimum values for the research variables.

In the regression model, the effect of the independent variables (OEPS, OCC) on the firm value of the sample firms is examined. A multivariate linear regression model is used at the 5\% significance level for testing the hypotheses. If there is no relationship between the independent variables and the dependent variable, all the coefficients in the regression model must be equal to zero. Thus, we can test the significance of the regression model, which is often done using F test. If the obtained F-statistic is less than the Table value of $\mathrm{F}$ at the $95 \%$ confidence level, the regression model will be significant. The results of F-test are provided in Table 4 $(\mathrm{P}<0.05)$. The results of estimating the regression model at the $5 \%$ significance level are provided in Tables. 
Table 2: Model Summary ${ }^{\mathrm{B}}$

\begin{tabular}{llllll}
\hline Model & $\mathrm{R}$ & R Square & $\begin{array}{l}\text { Adjusted R } \\
\text { Square }\end{array}$ & $\begin{array}{l}\text { Std. Error of } \\
\text { the Estimate }\end{array}$ & $\begin{array}{l}\text { Durbin- } \\
\text { Watson }\end{array}$ \\
\hline 1 & $.346^{\mathrm{a}}$ & .120 & .102 & .4090368 & 1.275 \\
\hline 1) & Predictors: (Constant), leverage, size, OEPS & \\
2) & Dependent Variable: val
\end{tabular}

Table 3: The Results of Estimating the Regression Model (1)

\begin{tabular}{|c|c|c|c|c|c|}
\hline \multirow[t]{2}{*}{ Model } & \multicolumn{2}{|c|}{$\begin{array}{l}\text { Unstandardized Coeffi- } \\
\text { cients }\end{array}$} & \multicolumn{2}{|l|}{ Standardized } & \multirow[t]{2}{*}{ Sig. } \\
\hline & B & Std. Error & Beta & & \\
\hline \multirow{4}{*}{$\begin{array}{l}\text { (Constan } \\
\text { OEPS }\end{array}$} & ) 1.418 & .368 & & 3.852 & .000 \\
\hline & .000 & .000 & .157 & 2.001 & .047 \\
\hline & .007 & .026 & .019 & .251 & .802 \\
\hline & -.466 & .129 & -.284 & -3.610 & .000 \\
\hline
\end{tabular}

a) Dependent Variable: val

Table 4: ANOVA $^{\mathrm{A}}$

\begin{tabular}{|c|c|c|c|c|c|}
\hline Model & $\begin{array}{l}\text { Sum of } \\
\text { Squares }\end{array}$ & $\mathrm{df}$ & $\begin{array}{l}\text { Mean } \\
\text { Square }\end{array}$ & $\mathrm{F}$ & Sig. \\
\hline Regression & 3.332 & 3 & 1.111 & 6.639 & $.000^{\mathrm{b}}$ \\
\hline Residual & 24.427 & 146 & .167 & & \\
\hline Total & 27.760 & 149 & & & \\
\hline
\end{tabular}

a) Dependent Variable: val

b) Predictors: (Constant), leverage, size, OEPS

Hypothesis 1

According to the first hypothesis, OEPS is significantly associated with VAL. Based on the results of multivariate regression model (Table 3); OEPS has a beta coefficient of 0.001 and p-value of 0.470. Therefore, there is no significant relationship between OEPS and firm value (VAL) at $5 \%$ significance level.

Table 5: Results of Testing the First Hypothesis with Multivariate Regression Analysis

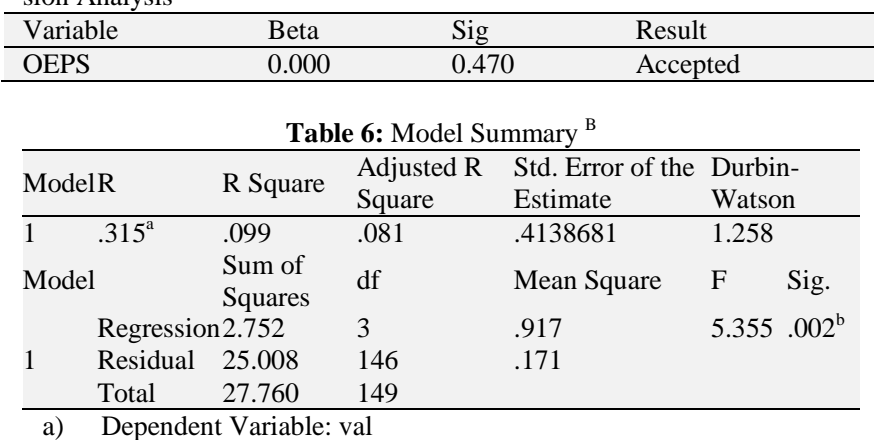

b) Predictors: (Constant), leverage, size, OCC

\begin{tabular}{llll}
\hline Variable & Beta & Sig & Result \\
\hline OCC & -0.224 & 0.471 & Accepted \\
\hline
\end{tabular}

Table 8: The Results of Estimating the Regression Model (1)

\begin{tabular}{|c|c|c|c|c|c|c|}
\hline \multirow{2}{*}{ Model } & \multicolumn{4}{|c|}{ Unstandardized Coefficients Standardized Coefficients } & \multirow[t]{2}{*}{$\mathrm{t}$} & \multirow[t]{2}{*}{ Sig. } \\
\hline & & Std. E & & & & \\
\hline \multirow{4}{*}{1} & (Constant) & 1.458 & .372 & & 3.920 & .000 \\
\hline & $\mathrm{OCC}$ & -.029 & .040 & -.057 & -.723 & .471 \\
\hline & size & .007 & .026 & .019 & .247 & .805 \\
\hline & leverage & -.513 & .129 & -.313 & -3.973 & 3.000 \\
\hline
\end{tabular}

a) Dependent Variable: val

Hypothesis 2

According to the second hypothesis, OCC is significantly associated with VAL. Based on the results of multivariate regression model (Table7), OCC has a beta coefficient of -0.029 and p-value of 0.471 . Therefore, there is significant relationship between OCC and VAL at 5\% significance level.

\section{Discussion and conclusion}

The present research examined the relationship between two variables (OEPS, OCC) and firm value of the Basic metals firms listed in Tehran Stock Exchange. The results of multivariate regression rejected one the hypotheses of the research. The results of multiple linear regression analysis show that there is a significant relationship between Overconfidence based on earning per share (OEPS) and firm value. Also, there is a significant relationship between Overconfidence based on capital cost (OCC) and firm value. This finding is consistent with results (Liu, Taffler, 2007). The first limitation is related to the lack of classified data in the database of TSE. Therefore, the researchers were forced to use the audited reports of the firms and data collection became a very time consuming process.

One-Sample Kolmogorov-Smirnov Test

\begin{tabular}{|c|c|c|c|c|c|c|c|}
\hline & & VAL & OEPS & OCC & SIZE & $\begin{array}{l}\text { LEVER- } \\
\text { AGE }\end{array}$ & $\begin{array}{l}\text { INDUS- } \\
\text { TRY }\end{array}$ \\
\hline \multirow[t]{2}{*}{$\mathrm{N}$} & & 150 & 150 & 150 & 150 & 150 & 150 \\
\hline & Mean & 1.72401 & 298.7066 & 6.19286 & 13.7045 & .552414 & 1.100000 \\
\hline \multirow{2}{*}{$\begin{array}{l}\text { Normal } \\
\text { Parame- } \\
\text { ters }{ }^{a, b}\end{array}$} & & & 7 & 8 & & & \\
\hline & $\begin{array}{l}\text { Std. } \\
\text { Devia- } \\
\text { tion }\end{array}$ & $\begin{array}{l}1.99087 \\
15\end{array}$ & $\begin{array}{l}261.5909 \\
91\end{array}$ & $\begin{array}{l}3.89764 \\
14\end{array}$ & $\begin{array}{l}.796103 \\
5\end{array}$ & .2206873 & .3010050 \\
\hline \multirow{3}{*}{$\begin{array}{l}\text { Most } \\
\text { Extreme } \\
\text { Differ- } \\
\text { ences }\end{array}$} & $\begin{array}{l}\text { Abso- } \\
\text { lute }\end{array}$ & .322 & .153 & .101 & .052 & .096 & .530 \\
\hline & Positive & e.322 & .083 & .098 & .052 & .042 & .530 \\
\hline & $\begin{array}{l}\text { Nega- } \\
\text { tive }\end{array}$ & -.280 & -.153 & -.101 & -.049 & -.096 & -.370 \\
\hline \multirow{2}{*}{\multicolumn{2}{|c|}{$\begin{array}{l}\text { Test Statistic } \\
\text { Asymp. Sig. (2- } \\
\text { tailed) }\end{array}$}} & .322 & .153 & .101 & .052 & .096 & .530 \\
\hline & & $.000^{\mathrm{c}}$ & $.000^{\mathrm{c}}$ & $.001^{\mathrm{c}}$ & $.200^{\mathrm{c}, \mathrm{d}}$ & $.002^{\mathrm{c}}$ & $.000^{\mathrm{c}}$ \\
\hline
\end{tabular}

a) Test distribution is Normal.

b) Calculated from data.

c) Lilliefors Significance Correction.

d) This is a lower bound of the true significance.

\section{References}

[1] Ahmed, AS., Duellman, S. (2012). Managerial Overconfidence and Accounting Conservatism. Journal of Accounting Research 146(6) 2749-2759. http://dx.doi.org/10.2139/ssrn.2097895.

[2] Gervais, S., Heaton, J., \& Odean, T. (2003). Overconfidence, investment policy, and executive stock options. In L. Rodney (Ed.), Working paper. White Center for Financial Research, 15-021, (http://ssrn.com/abstract=361200).

[3] Liu, Y., Taffler, R. (2007). CEO Overconfidence in M \& A decision making and its impact on firm performance. Management School University of Edinburgh.

[4] Malmendier, U., Tate, G. (2005). CEO Overconfidence and Corporate Investment. Journal of Finance 6 2661-2700. http://dx.doi.org/10.1111/j.1540-6261.2005.00813.x.

[5] Pirmoradi F (2014). Impact of managerial overconfidence on the quality of earnings of the companies listed in Tehran Stock Exchange, the thesis of Master of Science, Islamic Azad University, Science and Research of Sirjan.

[6] Presley, T. Abbott, L. (2013). AIA submission: CEO overconfidence and the incidence of financial restatement. Advances in Accounting, Incorporating Advances in International Accounting 29: 74-84

[7] Skala, D. (2008). Overconfidence is Psychology and Finance-An Interdisciplinary Literature Review 143-33-50.

[8] Schrand, C. M., and. L. Zechman. (2011) "Executive Overconfidence and the slippery slope to Financial Misreporting." Journal of Accounting and Economics 53: 311329 http://dx.doi.org/10.1016/j.jacceco.2011.09.001.

[9] Van der Steen, E. (2004). Rational over optimism (and other biases) American Economic Review, 94(4), 1141-1151. http://dx.doi.org/10.1257/0002828042002697. 